Volume 12 Number 4, October-December 2018: pp. 355-367. Copyright (c) 2018 FIAT JUSTISIA. Faculty of Law, Lampung University, Bandarlampung, Lampung, Indonesia. ISSN: 1978-5186 | e-ISSN: 2477-6238.

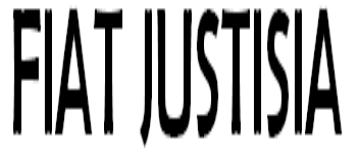

Fiat Justisia is licensed under a Creative Commons Attribution 4.0 International License, which permits unrestricted use, distribution, and reproduction in any medium, provided the original work is properly cited.

\title{
Gender Equality Issues in Optical Feminist Jurisprudence and Implementation in Indonesian
}

\author{
Heri Setiawan \\ University of Tarumanagara, Indonesia \\ heriwawan666@gmail.com \\ Steven Ouddy \\ University of Tarumanagara, Indonesia \\ stevenouddy17@gmail.com \\ Mutiara Girindra Pratiwi \\ University of Tarumanagara, Indonesia \\ mutiaragirindrapratiwi@gmail.com
}

\begin{abstract}
Gender meaning of fundamentally different from biological sex. Biological sex is a gift; we are born as a man or a woman. However, the path that makes us masculine or feminine is a combination of the building blocks of basic biological and biological interpretation by our culture. From the tiny baby to reach old age, we learn and practice specific ways that have been determined by the community for us to be men and women. Gender is a set of roles as well as costumes and masks at the theater, convey to others that we are feminine or masculine. Device specific behaviors include appearance, dress, attitude, personality, work inside and outside the household, sexuality, family responsibilities and so together polish "gender roles" us. If someone mentions or asks about gender, then what is meant is gender in the context of language approach. This term became very commonly used in the last few decades. Feminist jurisprudence is a legal philosophy that is based on gender equality in politics, economic and social. Feminist jurisprudence unpacks and explain how the law plays a role to legalize the status of women in subordination to men, in other words, the law as a means to preserve the status quo, namely the dominance of men over
\end{abstract}


women. Moreover, feminist jurisprudence is also trying to make a change/transformation changing the status of women by changing laws and its approach and its stance on gender cases be more fair and balanced. This is an emancipatory project woman in law.

Keywords: Gender, Feminist Jurisprudence, Justice, Men and Women.

How to Cite: Heri Setiawan, Steven Ouddy, and Mutiara Girindra Pratiwi, "Gender Equality Issues in Optical Feminist Jurisprudence and Implementation in Indonesian”, Fiat Justisia, 12 (4), (2018).

DOI: https://doi.org/ 10.25041/fiatjustisia.v12no4.1386

\section{A. Introduction}

Gender meaning of fundamentally different from biological sex. Biological sex is a gift, we are born as a man or a woman. However, the path that makes us masculine or feminine is a combination of the building blocks of basic biological and biological interpretation by our culture. From the tiny baby to reach old age, we learn and practice specific ways that have been determined by the community for us to be men and women. Gender is a set of roles as well as costumes and masks at the theater, convey to others that we are feminine or masculine. Device specific behaviors include appearance, dress, attitude, personality, work inside and outside the household, sexuality, family responsibilities and so together polish "gender roles" us. ${ }^{1}$

The gender term if reviewed in a terminological perspective is an absorption word taken from English. This gender word if seen from its position regarding language structure (grammatical) is a form of the noun (noun) which refers to the meaning of sex, sex, or called al-jins in Arabic. So if someone mentions or asks about gender, then what is meant is gender in the context of language approach? According to the author, the gender term is still a fairly new vocabulary that enters the vocabulary of the Indonesian language. This term became very commonly used in the last few decades. ${ }^{2}$

One of the most interesting things about the role of gender is, roles that change over time and vary from one culture to another culture. The role was also strongly influenced by social class, age and ethnic backgrounds. That gender inequality persist because so-called culture and habits justifies marginalization of women ${ }^{3}$

\footnotetext{
${ }^{1}$ Julia Cleves Mosse, Gender dan Pembangunan, Yogyakarta: Pustaka Pelajar, (2003), p.2.

${ }^{2}$ Peter Salim, Advance English-Indonesia Dictionary, Jakarta: Modern English Press, (1991), p. 384

${ }^{3}$ Ibid.
} 
The gender gap is a reality that must be faced by women in almost all parts of the world and can be found on the sphere, public to private, from domestic affairs to reproductive problems. In a public organization can be said to be in the position of marginalized women. There are several branches in this theory, which is Marxist feminists, socialist feminists and liberal feminist. Marxist Feminist stated that there is a gender division of classes, divided into male and female are implemented unfairly in life, so that they (women) between classes requires gender equality (gender). Socialist Feminist stated that socialist principles should be used to alleviate gender oppression. On the other hand, the Liberal Feminist stated that there is a difference in treatment between male labor force by women, so that the necessary equality of treatment intergender. The third branch of the flow demand for gender equality because of its nature, as in the case of property, rights of women workers and women's rights in law and politics.

One result is the marginalization of gender inequality, particularly against women. The assumption that women are weak creatures, soft, smooth. Sensitive and other feminine nature makes it not have an opportunity equal with men.

Their rights to be treated equally with men are marginalized, even displaced and do not uphold humanity. Women are considered second class citizens.

Simone de Beauvoir The Second $\mathrm{Sex}^{4}$

Indonesia has one case that was closely related to the issue of feminism was the industrial relations dispute case between the female teachers of the Pertamina Dumai Employee Welfare Foundation as plaintiffs against the Pertamina Employee Welfare Foundation (YKKP) Dumai as defendants as stated in the Supreme Court's cassation decision. 1604 K / Pdt / 2004. In this case, a dispute arose because YKKP imposed a discriminatory mode on the female teachers, where they did not obtain the same natural rights as those obtained by male workers. The thing that happens is that women workers even though they are married and have children continue to be treated as single status workers, so they do not get allowances for their husbands/children, while male workers who have a family get benefits for their wives/children. This is a form of discriminatory injustice because it eliminates women's natural rights, so that gender inequality occurs.

In its legal considerations, the panel of judges stated that the YKKP company regulations governing the discrimination of the rights of women and men workers were not legally enforced because they contradicted the principle of equal rights between gender. By nature, women (like men) will

\footnotetext{
${ }^{4}$ Simone de Beauvoir, "The Second Sex", and Jean-Paul Sartre, Dorothy Kaufmann McCall, Signs, 5 (2), (1979), pp. 209-223
} 
have a family, and women (like men) have the same rights to work and get a decent living, so women and men have the same rights to obtain facilities on income and employment benefits without gender discrimination. This is where the application of feminist jurisprudence is seen in judicial decisions in Indonesia, namely that gender differences cannot be used as a reason for differences in income payments or benefits by the company. ${ }^{5}$

Given what championed by feminists that women are also entitled engaged in social, political and economic. The lives of women who have only been home and family, making the creatures are passive and do not move in the public sphere, it is not because women are not capable, but more because of the absence of other alternatives. Then the feminist struggle must continue buzzed particularly with involvement in politics and law because women are also able to engage in public life like a man, like contributing to the political and social fields. Based on the description above background, the problems studied by the author wanted, namely: How is Gender Equality in Feminist Jurisprudence Optics implemented in Indonesia? And Is Gender Equality by Feminist Jurisprudence by the application in Indonesia?

\section{B. Method}

This journal writing method using a writing normative. Normative research is legal research theoretical. It is so called because in this normative research, focused on the study says that using secondary data such as the use of legislation and the form of the scientific work of scholars in our paper entitled "Gender Equality Issues in Feminist Jurisprudence Optics and Its Implementation in Indonesia," the author using a source of books and articles as ingredients that we use in our writing these problems so that normative.

Data collection techniques we obtain a library of materials called secondary data. Secondary data include primary legal materials and secondary legal materials. In this paper, we use the primary legal materials, and secondary law Materials Primary Law, legal materials consisting of legislation, formal treatise, court decisions, and official documents state. ${ }^{6}$ Materials Secondary Law is a law material consisting of books or journals law which contains the legal principle, doctrine, and the results of legal research, legal dictionary, legal encyclopedia and interviews with sources lawyer. $^{7}$

\footnotetext{
${ }^{5}$ http://business-law.binus.ac.id/2014/05/27/implementasi-feminist-jurisprudence-dalamperadilan-indonesia/ accessed on October 27, 2018 at 20:01 PM

${ }^{6}$ Fajar Mukti ND and Achmad Yulianto, Dualism Normative and Empirical Legal Research, Prints All 1, Yogyakarta: Learning Library, (2010), pp. 42-43.

${ }^{7}$ Ibid., p. 43.
} 


\section{Discussion}

\section{Birth history Feminist Jurisprudence}

Speaking about the law, we will be dealing with science with the target object is almost endless. The object named a law that has become so widespread because of it in contact with a large number of aspects of human life, call it the man himself, the community, the country's political, social, economics, history, psychology, philosophy and other aspects of life to another.

Feminist Legal Theory or Feminist Legal Theory (FLT) first appeared in the 1970s, along with the development of the movement of Critical Legal Studies (CLS) in America. CLS is the latest thought in legal theory, introduced in the 1970s, precisely starting in 1977 in the United States, with initiators such as Roberto Mangabeira Unger and Duncan Kennedy who are considered the main figures of the CLS movement, another name considered by CLS thought developers such as Morton Horwitz, David Trubek, Peter Gabel, Karl Klare, Kelman, and Mark Tushnet. Conference on Critical Legal Studies which was founded in 1977 is a national organization of CLS movement thinkers and activists consisting of legal practitioners, professors and students, social scientists, and other parties who are committed to the development of a critical theoretical perspective on law, legal practice and legal education. "Their perception of legal scholarship is radical, in the sense that the study of law should result in criticism, revaluation of institutions and social transformation." 8

In its development, CLS can be considered as failing to become a movement. There is a difference of opinion within CLS itself when they have to define more clearly "what is CLS?" Now CLS recedes as a movement, denying Freeman quoted by Ratnapala as almost cynically saying, "[CLS movement] like a meteor the Crits appeared, shone brightly for a short time and have gone."

However, it is recognized that the CLS idea continues to energize "left" criticism of liberal law, and as long as the CLS movement takes place successfully at least force liberal legal theorists to review, revise, and sharpen their views. But the influence of the movement and the idea of CLS in Feminist Legal Theory that developed into Liberal Feminism, Radical Feminism, Marxist and Socialist Feminism, Psychoanalytic and Gender Feminism, Existentialist Feminism, Postmodern Feminism, Multicultural and Global Feminism, and Ecofeminism and Race Theory Critical Race Theory is very inspiring and rich.

\footnotetext{
${ }^{8}$ Hari Chand, Modern Jurispridence, Kuala Lumpur: International Law Book series, (1994), p. 244
} 
As a thought that trying to make a breakthrough against the force of the law against discrimination of women and women of law obtained, the mainstream of feminist legal theory can be said to have similarities with the CLS. Therefore in some discussion of Jurisprudence, feminist legal theory included as a chapter in the discussion of CLS. ${ }^{9}$

The parties argued Feminist Legal Theory states that the CLS even though highlighting the legal enforceability solely from the standpoint of men, as well as the thoughts of other Jurisprudence. It is said that the law and legal theory is the land of men, are men who compose the laws and theories about subsequent law, the law, and the decision results reflect the values male or masculine values. Men who build the legal world that is then affect other groups that are not represented in these values. The values that were already such adhesions that are considered the general and absolute value to negate the value of the other.

Other criticisms of CLS, especially for the 4 (four) main aspects of CLS theory building, are conducted by Ratnapala as follows: a. Aspects of fundamental contradictions in society, according to Ratnapala critic Duncan Kennedy who said Western legal thinkers did not recognize the contradiction in which "numberless conformities, large and small abandonment of self to others, are the price of freedom we experience in society. And the price is a high one, "isn't true. Because liberals and Republicans (in the US of course) are always aware and fearful that collective power will have bad consequences rather than produce better, "They are acutely aware that the government's people are going to gain lives of their own and threaten individual freedom unless checks and balances contain them. "; b. The aspect of alienation through categorization and reification. According to P. Gable, the CLS thinker activist that, "the categories of stereotypes or pigeonhole individuals into particular roles and destroy their sense of personhood and interconnectedness" according to Ratnapala, this idea is meaningless, because if a citizen says even though he undergoes various roles in his life, he feel still an individual and have a relationship. CLS will answer, "You say so because it has been indoctrinated and conditioned to think so, you are alienated."; c. The aspect of rejection of the neutrality of values from the law, where it is believed that there is an objective, impartial and autonomous system of rules and procedures.

Ratnapala acknowledged that this thought was the strongest of CLS in rejecting the free value of the liberal legal system in its abstract, not the special concept. In a special sense of criminal law, there is no liberal thinker or practitioner who claims that punishing murderers, thieves, robbers or

\footnotetext{
${ }^{9}$ Niken Savitri, Women Rights Against Criticism Feminist Legal Theory of the Criminal Code, Jakarta: Refika Aditama, (2008), p. 27.
} 
rapists is free of value, because the punishment clearly confirms moral standards. CLS thinks liberals believe in the neutrality of law in an abstract sense, where the law serves a variety of social values and goals. Ratnapala said, CLS was right in questioning legal neutrality, but he said, "the laws of liberal societies are not ideologically clear cut. There is a continuous political tug-of-war between the ideals of impersonal abstract rules and discretionary power to determine rights and duties. It is, nevertheless, a battle of political values." 10

Then the last one that Ratnapala criticizes is d. The aspect of the world of alternative law from CLS, especially related to Roberto M. Unger's idea of a "super liberal" society with four types of rights directly answered by Ratnapala as an impossible project, "Unger's super liberal society at a glance seems unfeasible. Its economy needs a government to manage the allocation of resources for producing the means of existence. This is detailed to socialist command and control that has been tried unsuccessfully. Unger's society also needs a government, however decentralized and fragmented, to define and enforce the four types that he recommends. How are these bodies constituted? If they are elected, how can we be sure that noble critical legal scholars are elected? How can elections be kept free of pressure group politics? How stable would such a political system be? Designing utopian systems is easy, but achieving them in the world of real people is hard."11

CLS legal studies the authors think is very relevant we use in analyzing legal processes in Indonesia, in analyzing the processes of formation and application as well as to analyze a legal doctrine and how it has a function to legitimate a particular social system or policy. The author thinks that an analysis is needed that can reveal "hidden political intentions" behind various concepts, doctrines and legal processes here.

To carry out the delegitimation process of the legal doctrine that has formed CLS flow uses the method of trashing, deconstruction, and genealogy. These three methods according to Prof. Hikmahanto Juwana is a knife for CLS analysis to uncover the legitimacy of legal doctrine that establishes the status quo in legal doctrine. ${ }^{12} 1$. Trashing is a technique to break or reject the legal thinking that has been formed. ${ }^{13}$ This technique is carried out to show unilateral contradictions and conclusions based on dubious assumptions; 2. Deconstruction is to dismantle the formed legal

\footnotetext{
${ }^{10}$ Ratnapala, Op.Cit., p. 222

${ }^{11}$ Ibid., p. 223

12 Juwana, Hikmahanto, "International Law in Economic Conflicts of Interest in Developing and Advanced Countries", p. 8

13 "...A big miscellaneous grab bag of techniques designed to dent the complacent message embedded in legal discourse, that the system has figured out the arrangement that are going to make social life about as free, just, and efficient as it ever can be.” Look: Juwana, Ibid., p.8.
} 
thinking that has been formed. By dismantling, reconstruction of legal thinking can be done $;{ }^{14}$. Genealogy is the use of history in conveying arguments. Genealogy is used because the interpretation of history is often dominated by those who have power. ${ }^{15}$ This historical interpretation is then used to strengthen legal construction. ${ }^{16}$

The practical application of these three methods is shown by Prof. Hikmahanto Juwana in a sub-topic entitled "The Success of Developing Countries in Changing the Face of International Law: The Common Heritage of All Mankind Principle" when Developing Countries were able to change the principle of res communis to the common heritage of all mankind unconsciously used three methods introduced by CLS thinkers. First, Developing Countries have been trashing by saying that the principle of res communis is not a universal principle followed by the modern international community. The principle of res communis is only in favor of developed countries which are countries that have capital, expertise, and technology. Second, Developing Countries do a deconstruction of the principle of res communis by saying that the principle of res communis only benefits developed countries. In the arguments of Developing Countries the benefits of the Joint Territory should not be enjoyed limited to those who can exploit, but all humanity. Therefore the principle of res communis should be abandoned. Third, Developing Countries apply genealogy techniques by revealing that developed countries have exploited many natural resources contained in the Joint Territory without regard to the interests of other countries in the world. Therefore, it is time for the traditional principle to be replaced so that it does not discriminate against countries that do not have the technology, capital, and expertise. ${ }^{17}$

About feminist legal studies was born to fight for justice for oppressed women, and legal studies should not only apply the principles of certainty

\footnotetext{
14 "The Crits do not believe, however, that their trashing reveals a random chaos or that what lies behind the seeming order of legal decisions is just pure power (or personal whim). There is patterned chaos, and the aim of Critical scholarship is in part to uncover the patterns. Some of their best work is a familiar kind of left-wing scholarship, unmasking the often unconscious ideological bias behind legal structures and procedures, which regularly makes it easy for business groups to organize collectively to pursue their economic and political interest but which makes it much more difficult for labor, poor people, or civil rights group to pursue theirs." Ratnapala, Ibid., p.8.

15 "Still another way to heighten awareness of the transitory, problematic, and manipulable ways legal discourses divide the world is to write their history. The Crits have turned out a lot of history of legal categories." Ibid., p.8.

${ }^{16}$ Juwana, Op.Cit., p. 8.

${ }^{17}$ Juwana, Op.Cit., pp. 11-12. The use of these three methods is also very interesting when Juwana discusses the sub-topic "The Failure of Developing Countries to Change the Face of International Law: Limiting Multinational Corporation's Motion.Lihat: Juwana, Op.Cit, pp. $18-24$
} 
but the very first principle of justice how to achieve this common goal, the efforts, and measures being tested for decades in many countries, which has led to various streams. But one thing common concerns is the establishment of legal studies which have a centuries-old and that fact also has spawned a variety of theories and streams, while the new feminist studies appeared exactly half a century ago. ${ }^{18}$

Usually, experts feminism in demand for learning to think in the way feminists, or the so-called think like a feminist. Although among the experts there is no uniform method, basically they are trying to put women as the focus of the study and not marginalized by certain legal assessment.

In legal positivism, the rule of law will only be realized if the law is regarded as a closed system and autonomous of the various moral issues, religion, philosophy, politics, history and the like. Questions about the fair, but as long as he is still valid, then the law must still be obeyed. For the followers of legal positivism, legal certainty will be achieved not only because of the law established by the competent authorities to follow the regulatory system in force, but also if the law can work both in the scientific framework with a variety of positive science (natural sciences and social sciences the way it works is based on the method of the natural sciences) to legitimize a variety of behaviors in the society.

\section{Relationships of Gender Equality and Feminist Jurisprudence}

Feminist legal theory or feminist jurisprudence is a legal philosophy that is based on gender equality in politics, economic and social - feminist Legal Theory based on the view that the feminist movement in history, the law is an instrument to perpetuate the subordination of women under the position of men. History written by men has created a bias in the concept of human nature, potential, and ability to gender, and in community settings. By claiming to-man early as the norm, then to the woman's was a deviation from the norm and this is the concept of hegemony and strengthening the legal and patriarchal power. ${ }^{19}$

As mentioned in an adage to equality before the law, that is the position of everyone is equal before the law regardless of gender, race, social status, and so, etc. For that feminist jurisprudence or feminist legal theory emerged as a form of criticism of the idea of the flow or understand the laws that already exist. Feminists challenge and dismantle the belief or myth that men and women are so different so that certain behaviors can be distinguished by gender difference. Gender determines the physical appearance, reproductive

\footnotetext{
${ }^{18}$ Gandhi Lapian, Discipline Laws Delivering Equality and Justice Gender, Jakarta: Pustaka Torch, (2012), p. 26.

${ }^{19}$ https: //www.academia .edu / 6363210 / UAS paper _ _ _ Philosophy of Law, accessed on September 18, 2018, p. 2.
} 
capacity, but does not specify the characteristics of psychological, moral or social. In other words, according to the author feminist jurisprudence trying to learn the law from the perspective of women and based on feminist theories. ${ }^{20}$

Along the way, feminist jurisprudence unpack and explain how the law plays a role to legalize the status of women in subordination to men, in other words, the law as a means to preserve the status quo, namely the dominance of men over women. Moreover, feminist jurisprudence is also trying to make a change/transformation changing the status of women by changing laws and its approach and its stance on gender cases be more fair and balanced. It is an emancipatory project woman in law.

Simply put, Feminist Jurisprudence is a legal philosophy that arises when men are always considered more dominant, and at the same time women are not taken into account. Complex, it is said that a philosophy of law based on gender equality in the political, economic and social fields as well as on the feminist movement views expressed in history that law is an instrument to perpetuate the position of women under the subordination of men. It is begins when there is discrimination against gender, in which the position of women in law and society is considered to be level or even some level lower than the position of men. Whereas in law the position of each person should be equal before the law without distinguishing gender, race, social status and so forth.

\section{Feminist Jurisprudence Law Implementation In Indonesia}

Indonesia adheres to legal positivism that no other law except the command authority or legal norms is valid when determined by the agency or the appropriate authorities and is based on the higher rules and not hung on moral values. Legal norm set out is none other than the law. The legislation is a source of law, outside the law is not the law.

Regulations in effect in this country as if soluble and immersed in the paradigm of "third world countries" which assumes that every movement of life need to be changed because it adapted to a global presence that would not be considered old-fashioned. Written rules (positive law) this country bias so only instrumental castle caste strata of social life and barely deviated from a philosophical goal formation. ${ }^{21}$ Feminists against sex segregation of the sexes. They cite a dialectical relationship between the two is seen as an interaction between the two. The two are not at all mutually exclusive, but it

\footnotetext{
${ }^{20}$ https://www.academia.edu / 6363210 / UAS paper _ _ _ Philosophy of Law, Accessed on September 18, 2018, p. 2.

${ }^{21}$ Mohammed Erwin, Philosophy of Law "Critical Reflection on the Law", Jakarta: King Grafindo Persada, (2012), p. 157.
} 
is said that the patriarchal dichotomy prevents us from seeing the other components of this interconnected. ${ }^{22}$

Legal Positivism theorists regard the law as a portrait of social reality or even social reality itself. So as to determine the form of sexual division of labor (the division of labor in society and households between men and women) the division of labor in society and households between men and women) who have and are being applied in Indonesia, a person is considered enough to read for example the Civil Code, the Marriage Law number 1 in 1974, and the Criminal Code.

Unlike the feminist legal minds that it is thus considered laws that marginalize women. Ratings like this are only possible because feminists see a link between the law of unequal power relations between women and men. For feminists, the laws are believed to neutral and unbiased by Legal theory Positivism impossible. Because we realize it or not many laws are made in the patriarchal perspective and thus better protect men than women.

Citing feminist Catherine MacKinnon, Nursyahbani Katjasungkana considers the formulation is based on the perspective of men "heterosexual" about sex, because it requires the "penetration of the penis into the vagina". It is happens because the science of law (written in the perspective of the theory of Legal Positivism) does not afford and do not want to interpret the gender discrimination that would reveal an interpretation of unequal power relations between women and men in society. For example, by seeing if the dignity or human rights of women has been torn to shreds? It is happens because the science of law (written in the perspective of the theory of Legal Positivism) does not afford and do not want to interpret the gender discrimination that would reveal an interpretation of unequal power relations between women and men in society. For example, by seeing if the dignity or human rights of women has been torn to shreds? This happens because the science of law (written in the perspective of the theory of Legal Positivism) does not afford and do not want to interpret the gender discrimination that would reveal an interpretation of unequal power relations between women and men in society. ${ }^{23}$

\section{Conclusion}

Through the above approach, the effort seems to have long been associated with the fight for gender equality. Regardless of whether someone is likely to be in one is, but the struggle for gender activists through feminism proved gradually and slowly has changed the perception, understanding, and treatment of the community at large. At least in the field

\footnotetext{
${ }^{22}$ Mukthie Fajar, Theories of Contemporary Law, Malang: Equivalent Press, (2014). p. 82.

${ }^{23}$ Ibid., p. 27
} 
of law, Indonesia has the Law on the Elimination of Domestic Violence, the Law on Child Protection, Law Trafficking Law on Political Parties and the Election Law on Citizenship, Law on Pornography, plan revision of the Marriage Act, and others.

However, some of these regulations still require more in-depth gender studies, especially about the implementation in the field. Thus, to achieve these goals, women still have to optimize its ability to be potential human resources. It can create the perception, existence, and opportunity for women who have been structured in a society becomes more open, including the building of the mother through the development of the quality family.

We urge that the efforts to create a good legal order as a state of law and to make the law as a means of renewal and community development. It is time for Indonesia should think about the legal culture for the future. A legal culture that grows in the unity of the state legal system. For that level of jurisprudence should be given as early as possible for the residents. Specific legal education has to be input in the education curriculum. So that the future can grow a good litigious culture of our society. We suggest to the creators of the legislation; it is good to make a rule to assess in advance the circumstances that exist at this time to be an umbrella for all legal proceedings are conducted. 


\section{Bibliography}

\section{A. Book}

Chand, Hari. (1994). (2003). Modern Jurisprudence. Kuala Lumpur: International Law Book series

Erwin, Mohammed. (2012). Philosophy of Law "Critical Reflection on the Law". Jakarta: King Grafindo Persada

Fajar Mukti ND and Achmad Yulianto. (2010). Dualism Normative and Empirical Legal Research, Prints All 1. Yogyakarta: Learning Library

Fajar, Mukthie. (2014). Theories of Contemporary Law. Malang: Equivalent Press

Lapian, Gandhi. (2012). Discipline Laws Delivering Equality and Justice Gender. Jakarta: Pustaka Torch

Mosse, Julia Cleves. Gender dan Pembangunan. Yogyakarta: Pustaka Pelajar,

Salim, Peter. (1991). Advance English-Indonesia Dictionary. Jakarta: Modern English Press

Savitri, Niken. (2008). Women Rights Against Criticism Feminist Legal Theory of the Criminal Code. Jakarta: Refika Aditama

\section{B. Journal}

Simone de Beauvoir, and Jean-Paul Sartre, Dorothy Kaufmann McCall, "The Second Sex”, Signs, 5 (2), (1979).

\section{Legislation}

Indonesia. The Book of the Law of Civil Law (Civil Code).

\section{World Wide Web}

http://business-law.binus.ac.id/2014/05/27/implementasi-feministjurisprudence-dalam-peradilan-indonesial accessed on October 18, 2018, at 20:01 PM

https: //www.academia .edu / 6363210 / UAS paper _ _ _ Philosophy of Law, accessed on September 18, 2018 